\title{
Engineering the cell surface display of cohesins for assembly of cellulosome-inspired enzyme complexes on Lactococcus lactis
}

\author{
Andrew S Wieczorek, Vincent JJ Martin ${ }^{*}$
}

\begin{abstract}
Background: The assembly and spatial organization of enzymes in naturally occurring multi-protein complexes is of paramount importance for the efficient degradation of complex polymers and biosynthesis of valuable products. The degradation of cellulose into fermentable sugars by Clostridium thermocellum is achieved by means of a multiprotein "cellulosome" complex. Assembled via dockerin-cohesin interactions, the cellulosome is associated with the cell surface during cellulose hydrolysis, forming ternary cellulose-enzyme-microbe complexes for enhanced activity and synergy. The assembly of recombinant cell surface displayed cellulosome-inspired complexes in surrogate microbes is highly desirable. The model organism Lactococcus lactis is of particular interest as it has been metabolically engineered to produce a variety of commodity chemicals including lactic acid and bioactive compounds, and can efficiently secrete an array of recombinant proteins and enzymes of varying sizes.

Results: Fragments of the scaffoldin protein CipA were functionally displayed on the cell surface of Lactococcus lactis. Scaffolds were engineered to contain a single cohesin module, two cohesin modules, one cohesin and a cellulose-binding module, or only a cellulose-binding module. Cell toxicity from over-expression of the proteins was circumvented by use of the nisA inducible promoter, and incorporation of the C-terminal anchor motif of the streptococcal M6 protein resulted in the successful surface-display of the scaffolds. The facilitated detection of successfully secreted scaffolds was achieved by fusion with the export-specific reporter staphylococcal nuclease (NucA). Scaffolds retained their ability to associate in vivo with an engineered hybrid reporter enzyme, E. coli $\beta$-glucuronidase fused to the type 1 dockerin motif of the cellulosomal enzyme CelS. Surface-anchored complexes exhibited dual enzyme activities (nuclease and $\beta$-glucuronidase), and were displayed with efficiencies approaching $10^{4}$ complexes/cell.
\end{abstract}

Conclusions: We report the successful display of cellulosome-inspired recombinant complexes on the surface of Lactococcus lactis. Significant differences in display efficiency among constructs were observed and attributed to their structural characteristics including protein conformation and solubility, scaffold size, and the inclusion and exclusion of non-cohesin modules. The surface-display of functional scaffold proteins described here represents a key step in the development of recombinant microorganisms capable of carrying out a variety of metabolic processes including the direct conversion of cellulosic substrates into fuels and chemicals.

\section{Background}

Macromolecular enzyme complexes catalyze an array of biochemical and metabolic processes such as the degradation of proteins [1,2] or recalcitrant polymers [3] as well as the high-yield synthesis of valuable metabolic products via substrate channeling [4]. From a biotechnological

\footnotetext{
* Correspondence: vmartin@alcor.concordia.ca

* Correspondence: vmartin@alcor.concordia.ca Canada
}

perspective, mimicking such process by incorporating catalytic modules or enzymes of interest within synthetic complexes can significantly enhance the efficiency of such bioprocesses via substrate channeling [5] and increased enzyme synergy [3]. In a cellulosome, multiple enzymes assemble into a macromolecular complex by their association with a scaffold protein for the efficient degradation of cellulose [6]. In the case of the gram-positive thermophile Clostridium thermocellum, the cellulosome is anchored to 
the surface of cells, resulting in one of the most efficient systems for bacterial cellulose hydrolysis [3,7].

Cellulosomal enzymes bear C-terminal type 1 dockerin (dock1) modules, which target them to a central scaffold protein (CipA) via chemically and thermally stable non-covalent interactions with one of nine cohesin (coh) modules [8]. CipA also contains a type 3a cellulose-binding module (CBM3a), allowing the different cellulases to act in synergy on the crystalline substrate, as well as a type 2 dockerin module which binds anchor proteins, ensuring the cellulosome's attachment to the cell $[9,10]$. Therefore, the architecture of the cellulosome establishes proximal and synergistic effects of enzymes within the complex when associated with the substrate $[8,11,12]$. These synergistic effects are further augmented by an extra level of synergy resulting from the cellulosome's association with the surface of cells, yielding cellulose-enzymemicrobe (CEM) ternary complexes [6,7,13-18]. CEM ternary complexes benefit from the effects of microbeenzyme synergy, ultimately limiting the escape of hydrolysis products and enzymes, increasing access to substrate hydrolysis products, minimizing the distance products must diffuse before cellular uptake occurs, concentrating enzymes at the substrate surface, protecting hydrolytic enzymes from proteases and thermal degradation, as well as optimizing the chemical environment at the substrate-microbe interface [6,7,13-16].

In this work, we describe the cell surface display of small cellulosome scaffold proteins in Lactococcus lactis, a first and necessary step for the eventual engineering of extracellular protein complexes in this, and other bacterial hosts. "Mini" scaffold proteins have been intracellularly expressed and purified from hosts such as Escherichia coli or Bacillus subtilis for the purpose of assembling mini-cellulosomes in vitro [19-23]. The production of mini-cellulosomes in vivo has also been reported in Clostridium acetobutylicum and B. subtilis, however, complex localization was limited to secretion into the culture supernatant $[24,25]$. More recently, the surface-display of mini-cellulosomes was described in Saccharomyces cerevisiae, in some cases enabling growth on cellulosic substrates [26-29]. However, there have been no reports on the recombinant assembly of cellulosome-inspired complexes on the surface of bacterial cells. For this purpose, we chose L. lactis, a gram-positive bacterium with established commercial value. L. lactis is of specific interest as it is generally regarded as safe (GRAS), has been used to produce valuable commodity chemicals such as lactic acid [30] and bioactive compounds [31], and has been successfully engineered to secrete and/or display on its cell surface, a wide variety of proteins ranging from 9.8 to $165 \mathrm{kDa}$ [32]. The metabolic engineering tools available in conjunction with the successful controlled expression and high-yield production of enzymes and proteins [32] make it an ideal candidate for the recombinant expression of cellulosomal components. Using L. lactis as a surrogate host, we successfully secreted fragments of $\mathrm{CipA}\left(\mathrm{CipA}_{\text {frags }}\right)$ to the cell surface and the scaffolds retained functionality. All scaffolds containing functional cohesins were capable of associating with an engineered test enzyme, E. coli $\beta$-glucuronidase (UidA) fused with a dockerin. We envision expanding on this work to eventually engineer larger scaffolds that will serve as the basis for assembling and immobilizing large extracellular enzyme complexes.

\section{Results}

Regulated expression of CipA $A_{\text {frags }}$ yields the surfacedisplay of scaffold proteins

L. lactis HtrA NZ9000 cells were successfully transformed with either the pAW500 series or pAW300 series of vectors (Fig. 1A), resulting in strains expressing fragments of CipA $\left(\mathrm{CipA}_{\text {frags }}\right)$ alone, or as fusions with the NucA export-specific reporter, and/or the $\mathrm{Cwa}_{\mathrm{M} 6}$ for anchoring of the scaffold to the cell-surface (Fig. 1B). Growth curves of engineered $L$. lactis strains were used to determine if the expression and secretion of scaffold proteins resulted in growth inhibition. Results from the growth experiments showed a correlation between cipAfrag gene expression and growth inhibition (Fig. 2). The constitutive over-production of recombinant proteins targeted to the cell surface in L. lactis may interfere with the integrity of the cell wall [33], whereas in C. thermocellum, the constitutive expression of CipA is modulated through catabolite repression [34]. In the absence of the inducer nisin, all $c i p A_{\text {frag-expressing }}$ strains grew similarly to the control L. lactis HtrA NZ9000 with a final cell density corresponding to an $\mathrm{OD}_{600}$ approaching 0.7 (Fig. 2A, D, G). This indicated that little change in growth profile resulted from any leaky expression of the recombinant proteins. Nisin induction at inoculation resulted in cellular toxicity, as demonstrated by extended lag phases, lower growth rates and final cell yields (Fig. 2B, E, H). In all cases, when induction of protein expression was carried out after 4 hrs of growth (corresponding to an $\mathrm{OD}_{600} \approx 0.3$ ), cultures did not display growth retardation and final cell densities were similar to those attained with no induction (Fig. 2C, F, I). Expression of the various $\operatorname{cip} A_{\text {frags }}$ from the constitutive $P_{59}$ promoter consistently resulted in plasmid rearrangements as observed by restriction digest analysis of the rescued plasmids from both $E$. coli and L. lactis (data not shown). From these results, we hypothesized that unregulated high-level expression of the Cip $\mathrm{A}_{\text {frag }}$ proteins was toxic to the cells and using a constitutive promoter such as $P_{59}$ induced plasmid 


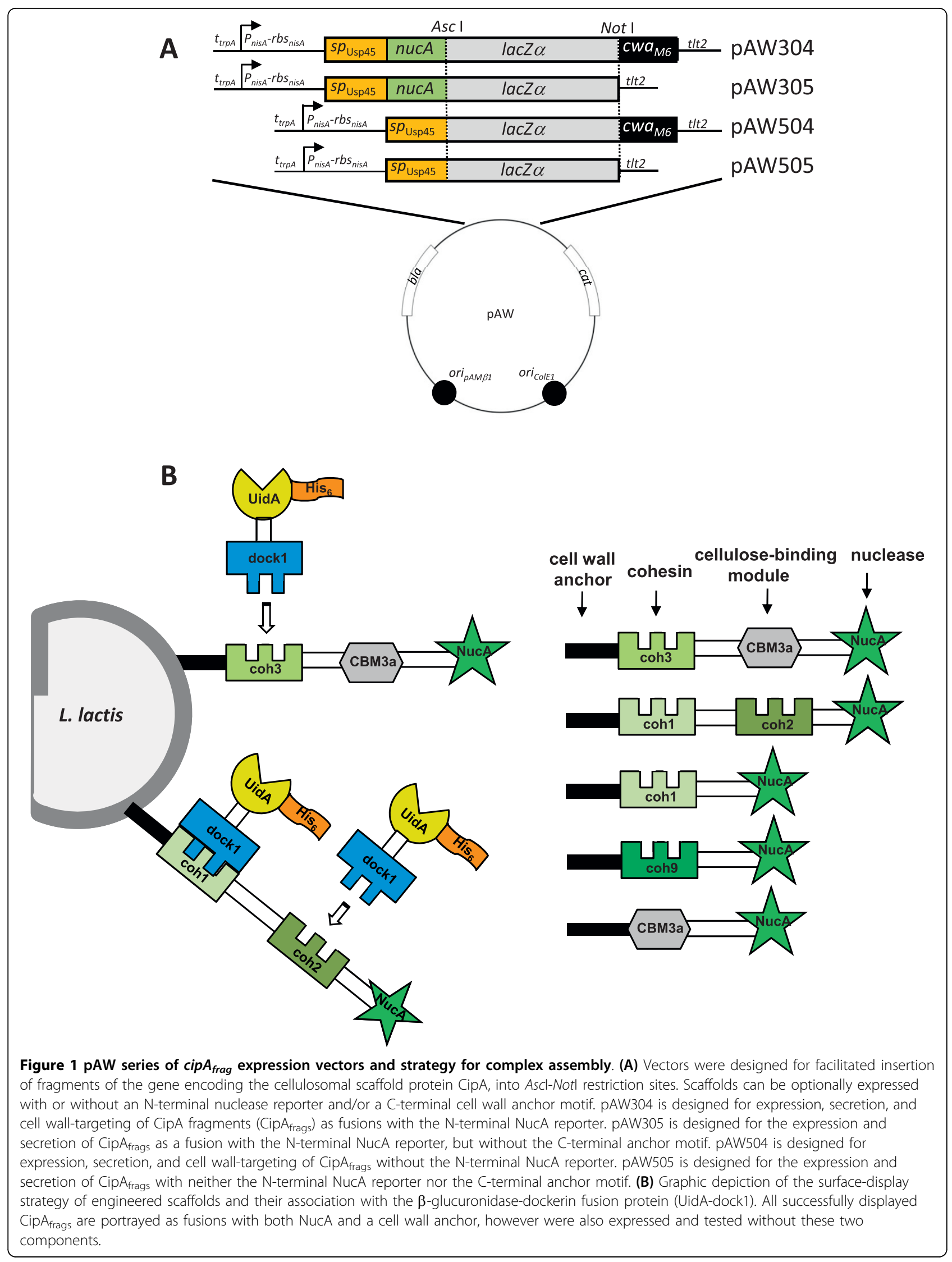




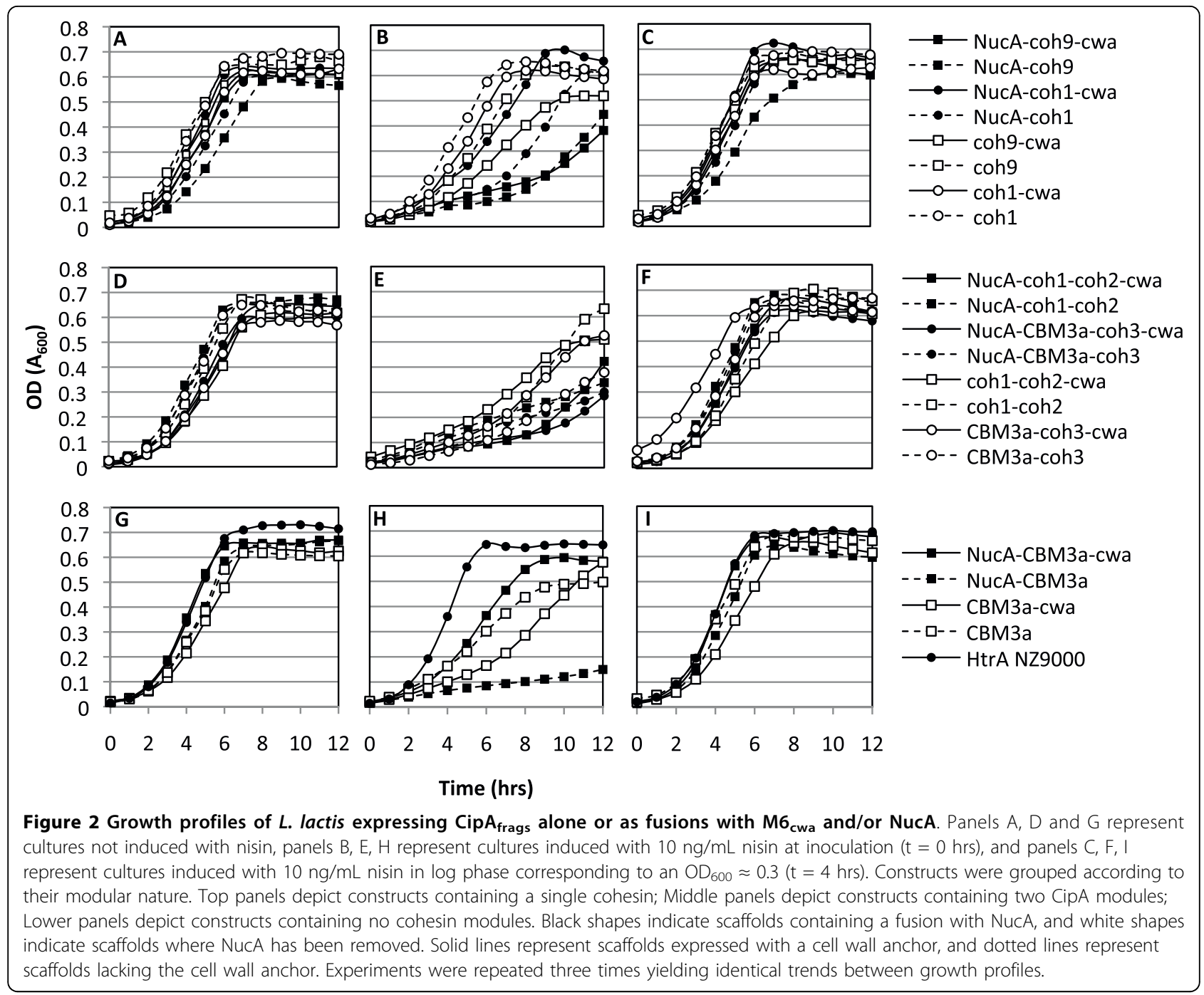

rearrangements that abolished or reduced $\operatorname{cip} A_{\text {frag }}$ expression. These results confirmed the necessity for regulating expression of the proteins, which was achieved using the $P_{\text {nis }}$ promoter. With the exception of cell wall anchored scaffold containing only a cellulose-binding module (CBM3a-cwa) (Fig. 2H), removal of the NucA lowered or eliminated toxicity to the cells, as observed by improved growth rates and yields.

\section{NucA-CipA frag proteins are localized to the cell wall of L. Iactis}

In order to quickly evaluate our success at recombinant protein secretion in L. lactis, a nuclease enzyme was fused to the CipA fragments to be displayed on the cell surface. L. lactis cells harboring the pAW300 series of vectors all displayed a $\mathrm{NucA}^{+}$phenotype on plates overlaid with TBD agar, confirming that all variants of the NucA-CipA frag proteins were successfully secreted and that the nuclease retained its function when expressed as an $\mathrm{N}$-terminal fusion to $\mathrm{CipA}_{\text {frags. }}$ To determine the cellular localization of the expressed $\mathrm{CipA}_{\text {frag }}$ fusion proteins, cell fractionations were performed, and cytoplasmic, cell wall, and supernatant fractions were spotted on TBD agar. Of the secreted NucA-CipA frag proteins, almost all detectable nuclease activity was found in the cell wall fractions corresponding to proteins released from lysozyme/lysostaphin treatments, suggesting successful cell wall targeting of the proteins (Fig. 3). CipAfrag proteins were not detected in the supernatant, suggesting that secreted proteins remained localized to the cell wall due to the activity of lactococcal sortase. Unexpectedly, the NucA-CipA frag fusions lacking the cell wall anchor domain were also detected primarily in the cell wall fractions (Fig. 3) suggesting that fusion of NucA with CipA $_{\text {frags }}$ caused the scaffolds to remain associated with the cell wall, even without covalent cross-linking by sortase. All of the cytoplasmic fractions were also found to contain varying levels of expressed 


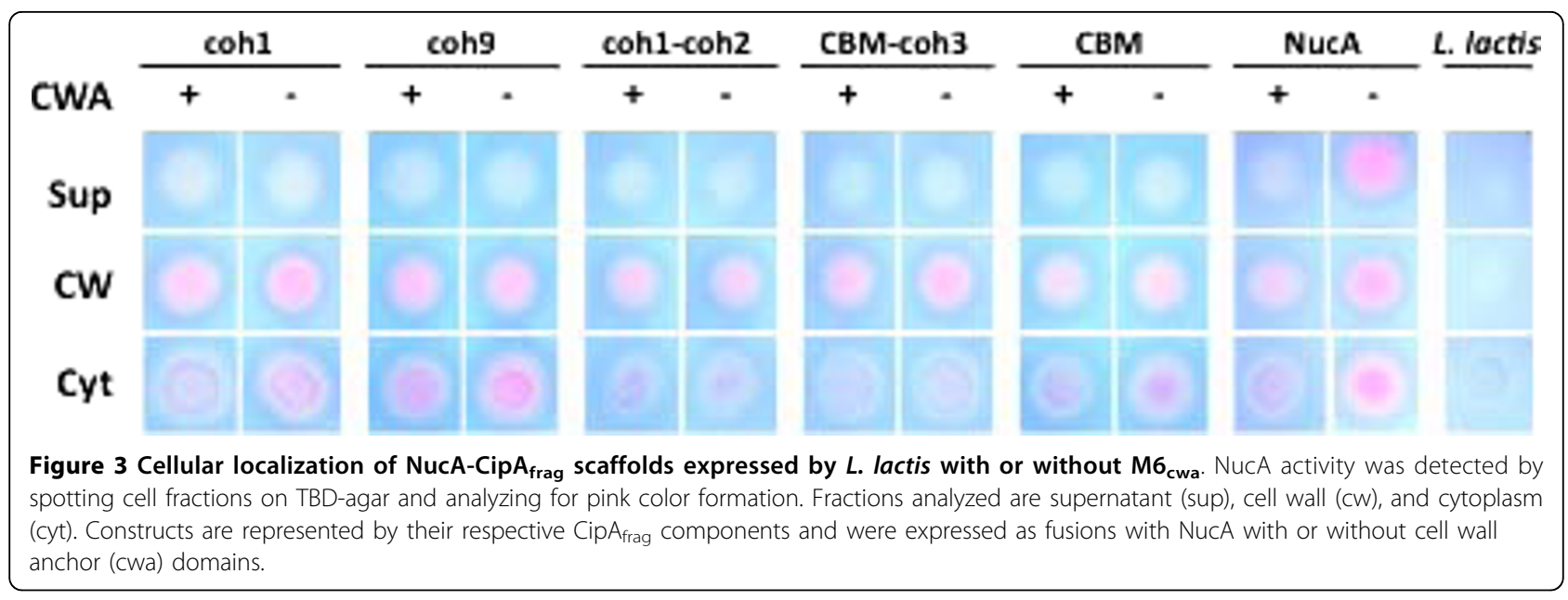

scaffolds, a finding consistent with observations previously made while exporting recombinant proteins in L. lactis [35-38]. We hypothesize that these cytoplasmic proteins were either in the process of being synthesized and exported by the cell via cytoplasmic chaperones, or had evaded the sec-pathway due to a lack of recognition of the signal sequence. In certain instances, the net charge of $\mathrm{N}$-terminal residues downstream of the signal peptide can also contribute to the poor secretion efficiency of recombinant proteins [39]. As expected from previous studies $[36,37]$ in the absence of a cell wall anchor domain, NucA was secreted into the supernatant but remained associated to the cell wall if the anchor domain was present (Fig. 3).

Cell surface displayed CipA $A_{\text {frag }}$ scaffolds bind UidA-dock1 In vivo binding assays were performed to determine if a dockerin-containing enzyme could associate with cell surface displayed CipA $A_{\text {frag }}$ scaffold proteins. L. lactis cells expressing cell wall and supernatant-targeted scaffolds were incubated with purified $\beta$-glucuronidase enzymes fused to a dockerin module (UidA-dock1). After incubation, washed cells were assayed for $\beta$-glucuronidase activity, allowing a relative comparison of $\mathrm{CipA}_{\text {frag }}$ display efficiencies between engineered constructs. All constructs containing cohesin modules as part of their scaffolds successfully bound UidA-dock1, while those lacking cohesins as well as the plasmid-free L. lactis HtrA NZ9000 failed to do so (Fig. 4). Binding experiments using UidA lacking dock1 resulted in no successful "docking" onto L. lactis displaying NucA-CBM3a-coh3 (Fig. 4A) or any other recombinant scaffolds (data not shown). These results demonstrated that functional recombinant scaffolds could be expressed on the surface of L. lactis and that cell surface complex formation was dependent on the presence of both cohesin and dockerin modules. Among those strains secreting and displaying functional scaffolds, significant variation in display efficiency was observed. Assuming a 1:1 enzyme-to-cohesin ratio, the approximate number of cohesins and/or scaffolds per cell was determined. The strains that displayed the greatest number of nuclease bearing scaffolds $\left(\sim 9 \times 10^{3}\right.$ scaffolds/ cell) were those expressing the cohesin 1 module alone (coh1-cwa and NucA-coh1-cwa) (Fig. 4). Strains expressing coh9-cwa, NucA-coh9-cwa, coh1-coh2-cwa, CBM3a-coh3-cwa and NucA-CBM3a-coh3-cwa, were estimated to display between $5.0 \times 10^{3}$ and $6.3 \times 10^{3}$ scaffolds/cell. These results suggested that the size of the $\mathrm{CipA}_{\text {frag }}$ is not necessarily the limiting factor influencing scaffold display. This was further observed with the relatively lower amount of enzymes binding to L. lactis displaying NucA-coh1-coh2-cwa $\left(1.5 \times 10^{3}\right.$ UidAdock1/ cell). Essentially, NucA-coh1-coh2-cwa is of similar size to NucA-CBM3a-coh3-cwa (approx. $68 \mathrm{kDa}$ ), contains twice as many cohesins, yet host cells where able to bind one quarter the amount of UidA-dock 1 molecules. The predicted molecular weights of the engineered scaffolds were used in order to estimate the net amount of recombinant protein on the cell surface of strains producing scaffolds with a single cohesin. The culture producing the highest net yield of functional recombinant protein was the strain anchoring NucA-CBM3a-coh3-cwa on its surface. Cultures produced and displayed approximately $0.72 \mathrm{mg} / \mathrm{mL}$ of recombinant scaffolds, which remained cell-associated and fully functional.

The effect of the $\mathrm{N}$-terminal nuclease reporter on secretion efficiency was also analyzed by comparing the binding capacity of $L$. lactis harboring the pAW300 series (nuclease fusions) with cells harboring the pAW500 (nuclease deficient) series of vectors. Initially included as a reporter to facilitate detection of exported scaffolds, we hypothesized that the nuclease fusion might also increase secretion efficiency, as has been previously observed [35,38]. Removal of NucA had no detrimental 


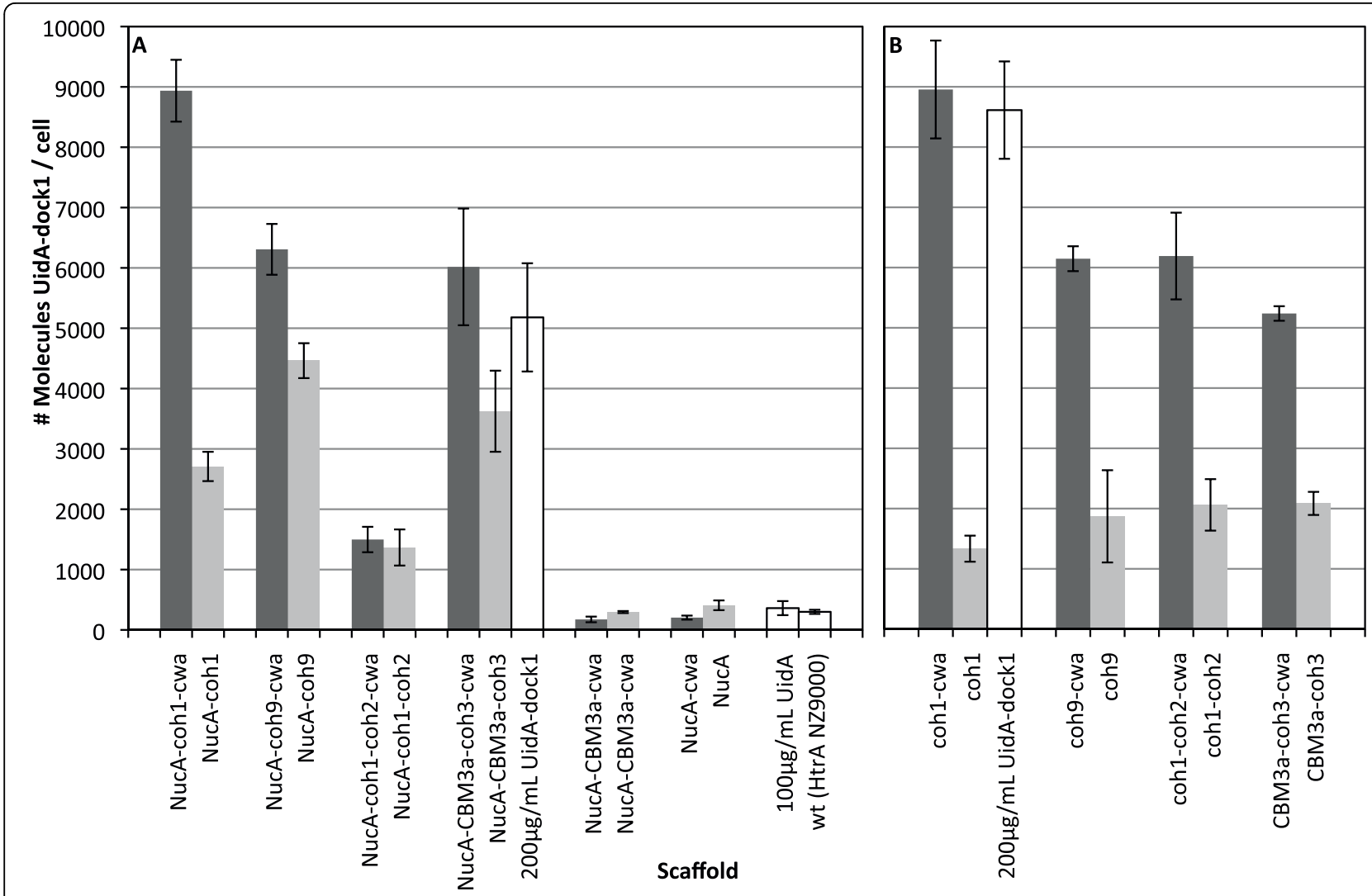

Figure 4 In vivo binding of UidAdock1 on live intact L. lactis cells displaying CipA $A_{\text {frags. }}$ CipA frags were expressed and anchored as fusions with the NucA reporter enzyme (A), or lacking the NucA reporter (B). Quantification of UidAdock1 molecules bound to L. lactis cells corresponds to equivalent amounts of functional cohesin assuming a 1:1 ratio of dockerin-cohesin association. Dark grey bars represent scaffolds containing the C-terminal M6 cell wall anchor motif ( $\mathrm{cwa}$ ), and light grey bars represent their anchor-deficient derivatives. White bars correspond to indicated controls; "200 $\mathrm{\mu g} / \mathrm{mL}$ UidA-dock1" represents binding assay carried out with excess enzyme and L. lactis pAW328 (NucA-CBM3a-coh3cwa) to ensure saturation of cohesins. "100 $\mu \mathrm{g} / \mathrm{mL}$ UidA" represents binding assay carried out in the presence of UidA and L. lactis pAW328 (NucA-CBM3a-cwa). Binding assay carried out with UidA and all other constructs resulted in no association with scaffold-expressing strains (data not shown).

effects on scaffold display for all constructs (Fig. 4B), as similar amounts of anchor-containing scaffolds were located to the cell surface. Furthermore, removal of NucA resulted in a fourfold increase in the amount of coh1-coh2-cwa successfully displayed when compared to its NucA-containing counterpart. The presence of NucA appeared to interfere with the secretion of supernatanttargeted scaffolds from the cell, given that the cwadeficient variants of coh1, coh9, and CBM3a-coh3 remained associated with the cell to a much larger extent than their NucA-deficient counterparts (Fig. 4).

\section{Discussion}

Several recent studies have reported on the recombinant expression of mini cellulosome scaffold proteins in Saccharomyces cerevisiae [26-29]. In these examples, the potential application of the engineered strains for the direct conversion of cellulosic biomass to ethanol was the driving factor for choosing S. cerevisiae as a host. However, many more platform strains have been or are now being developed that will produce ethanol, biofuels other than ethanol, and non-biofuel chemicals [5,14,40-47]. The economics of these processes would be greatly improved if these engineered microbes could use cellulosic substrates. With this goal in mind, the first logical step in establishing this system was the successful secretion and display of cohesin-bearing scaffold proteins. Previous studies have demonstrated that controlled gene expression in L. lactis can reduce toxicity and increase net protein yields $[33,48,49]$. In our study, the constitutive expression of the scaffold proteins consistently led to cellular toxicity, a problem that was solved by delaying the onset of gene expression until the cells had reached mid log-phase. In cell division, higher concentrations of recombinant cell wall-targeted proteins are localized to the septum, the site of cell wall biosynthesis [33]. It is thus likely that over-expression of our scaffold proteins targeted to the 
extracytoplasmic space early in the growth phase impaired cell wall biosynthesis and ultimately resulted in cell death. Removal of NucA from the scaffolds decreased or eliminated cellular toxicity for all cohesin-containing constructs (Fig. 2), and we thus suspect that accumulation of NucA in the cytoplasm may also contribute to this observed lag in the onset of growth when induced at $t=0$ hrs. In addition, as a larger proportion of scaffolds lacking a cell wall anchor remained trapped in the cell wall when fused with NucA, it is also likely that part of this observed reduction in toxicity is due to a decrease in the amounts of recombinant proteins being trapped in the cell wall and ultimately disrupting its integrity.

Quantification of cell surface displayed proteins in lactic acid bacteria was previously reported using fluorescence-activated cell sorting, flow cytometry, or wholecell ELISA [50]. In our assay, functionality of the displayed CipA frag scaffold proteins could be tested directly through binding with a dockerin-containing reporter enzyme, attesting that the number of cohesins detected was a direct quantification of those that retained biochemical function. Of the four expressed CipA fragments containing at least one cohesin (coh1, coh9, coh1-coh2, CBM3a-coh3), coh1 was displayed with the highest efficiency $\left(\sim 9 \times 10^{3}\right.$ scaffolds per cell $)$. Due to its small size and decreased number of modules compared with coh1-coh2 and CBM3a-coh3, we attribute part of this increase in display to the decrease in size of the scaffold itself. However, coh1 was also displayed more efficiently than coh9, which is approximately the same size and similar in primary amino acid sequence. One possible explanation may relate to the position of coh1 relative to coh9 on native CipA scaffold. Coh1 is located at the $\mathrm{N}$-terminus of the $200 \mathrm{kDa}$ scaffold CipA, adjacent to the processing site of the signal peptide by the sec-pathway machinery of C. thermocellum [7]. It is possible that the increase in secretion efficiency of coh1 when compared with coh9 may be in some part due to differences in amino acid content adjacent to the signal peptide, possibly increasing its accessibility to the chaperones involved in its transport to the extracytoplasmic space [51]. This, however, does not account for the differences in display efficiency between NucA-coh1 and NucA-coh9, as in both cases, NucA is adjacent to the signal sequence. The amount of sequence identity among cohesins perhaps provides a better explanation for these observed differences. Of the nine cohesin modules on CipA, cohesins 3 through 8 show between 96 to $100 \%$ sequence identity, whereas among the remaining cohesins, coh1 and coh9 show the least amount of sequence identity (69 and $75 \%$, respectively) [52]. These differences in amino acid content may translate into differences in folding and solubility of the recombinantly expressed modules.

L. lactis was engineered to display a scaffold containing 2 cohesin modules (coh1-coh2). Based on a 1:1 binding ratio of the enzyme-cohesin and assuming equivalent expression and secretion, we expected this strain to bind twice the amount of UidA when compared to scaffolds of similar size but containing a single cohesin module (i.e. CBM3a-coh3). However, coh1-coh2 bound similar amounts of UidA as CBM3a-coh3 (Fig 4B). This reduction in UidA binding was not attributed to $\mathrm{CipA}_{\text {frag }}$ size differences, since both mature scaffolds have a theoretical molecular weight of $68 \mathrm{kDa}$, suggesting that other factors affected secretion and display efficiency. In fact, protein size is not regarded as a major bottleneck for protein secretion in L. lactis, as the size of successfully secreted heterologous proteins ranges from $6.9 \mathrm{kDa}$ to a staggering $165 \mathrm{kDa}$ [32]. We hypothesize that the substitution of a cohesin module by CBM3a may have enhanced secretion by increasing the rate of folding of the scaffold into its soluble form. A similar effect was recently reported with the fusion of the highly insoluble Clostridium cellulovorans cellulase CelL with the CBM of cellulase CelD, which resulted in dramatic increases in its solubility [53].

Comparisons between amounts of UidA binding to cells expressing $\mathrm{CipA}_{\text {frags }}$ with or without the $\mathrm{cwa}_{\mathrm{M} 6}$ domain revealed that the cell wall anchor motif significantly increased the amounts of functional scaffolds displayed on the cell (Fig. 4). With NucA present, CipA frags lacking $\mathrm{Cwa}_{\mathrm{M} 6}$ remained cell-associated to a larger extent (Fig. 3) and bound UidA (Fig. 4), suggesting that NucA fusion proteins remained trapped in the cell wall for reasons other than covalent cross-linking by the sortase, but yet the cohesin modules were accessible to UidA. This phenomenon is well-documented in other studies of protein secretion in L. lactis, as in some cases the fusion of two generally well-secreted proteins results in changes in the folding of the hybrid protein, and deficiencies in their release from cells $[37,54]$. While the exact mechanism of this phenomenon is not clear, hydrophobic domains resulting from fusing two recombinant proteins may promote cell wall association [37].

\section{Conclusions}

Until now, all attempts to anchor enzymes on the surface of a bacterium have been limited to a single enzyme per anchor [33,35,36,38,50,55-61]. In our system, multiple enzymes could theoretically associate with scaffolds containing a corresponding number of cohesins. We used purified $\beta$-glucuronidase fused to a dockerin module as a probe to establish proper display and function of the cohesins, but envision co-expression of enzymes 
and scaffold in a subsequent development of the strain. We thus envision that further development of this cellulosome-inspired system may contribute to the efficient bioconversion of substrates into industrially relevant fuels and commodity chemicals, and that tailor-designed synthetic macromolecular complexes could be engineered to contain large permutations and combinations of desired enzymes of interest.

\section{Methods}

\section{Bacterial strains and plasmids}

The bacterial strains and plasmids used in this study are listed in Table 1. E. coli strains were grown in LuriaBertani medium at $37^{\circ} \mathrm{C}$ with shaking $(220 \mathrm{rpm})$. Lactococcus lactis HtrA NZ9000 was grown in M17 medium [62] supplemented with $1 \%(\mathrm{w} / \mathrm{v})$ glucose (GM17) at $30^{\circ} \mathrm{C}$ without agitation. C. thermocellum was grown in ATCC1191 medium at $55^{\circ} \mathrm{C}$ with $0.2 \%(\mathrm{w} / \mathrm{v})$ cellobiose as a carbon source. Where appropriate, antibiotics were added as follows: for E. coli, ampicillin $(100 \mu \mathrm{g} / \mathrm{mL})$, erythromycin $(150 \mu \mathrm{g} / \mathrm{mL})$, chloramphenicol $(10 \mu \mathrm{g} / \mathrm{mL})$ and kanamycin $(30 \mu \mathrm{g} / \mathrm{mL})$; for L. lactis, erythromycin $(5 \mu \mathrm{g} / \mathrm{mL})$ and chloramphenicol $(10 \mu \mathrm{g} / \mathrm{mL})$. General molecular biology techniques for $E$. coli were performed as previously described [63]. Genomic DNA was isolated from $C$. thermocellum as previously described [64]. To make competent cells, $L$. lactis was grown in M17 medium [62] supplemented with $1 \%(\mathrm{w} / \mathrm{v})$ glucose, $25 \%$ $(\mathrm{w} / \mathrm{v})$ sucrose and $2 \%(\mathrm{w} / \mathrm{v})$ glycine and cells were transformed as previously described [65]. M17 media was supplied by Oxoid, LB media was supplied by Novagen, all antibiotics, $\rho$-nitrophenyl- $\beta$-D-glucuronide and nisin were provided by Sigma, and X-gal and IPTG were supplied by Fermentas.

\section{Assembly of cassettes for scaffold protein expression and targeting}

The E. coli-L. lactis shuttle vectors pVE5524 and pVE5523 were used as backbone plasmids for targeting fragments of the CipA scaffold protein to the cell surface or supernatant, respectively [36]. The various $\mathrm{CipA}_{\text {frags }}$ were produced as fusions with the $\mathrm{N}$-terminal signal peptide from the lactococcal Usp45 secreted protein $\left(\operatorname{sp}_{U \text { sp45 }}\right)$ and for targeting to the cell wall, as a fusion with the C-terminal anchor from the Streptococcus pyogenes M6 protein $\left(\mathrm{cwa}_{\mathrm{M} 6}\right)$ (Fig. 1). Expression cassettes were designed to allow the optional fusion of $\mathrm{CipA}_{\text {frags }}$ with an $\mathrm{N}$-terminal nuclease reporter (NucA) used for detection of the fusion proteins in the extracellular milieu [35,38] (Fig. 1). The strong constitutive lactococcal promoter $P 59$ [36] and the $P_{\text {nisA }}$ nisin-inducible promoter from the nisA gene of L. lactis [66] were tested for optimal expression of the recombinant scaffolds. Two ribosome-binding sites were also tested, that of the usp 45 gene $\left(r b s_{u s p 45}\right)$ [36] and that of the nisA gene $\left(r b s_{\text {nisA }}\right)$ [66]. In order to facilitate the exchange of scaffold fragments in the expression cassette, AscI-NotI restriction sites were engineered just downstream of $n u c A$ (Fig. 1). To achieve this, an 800-bp fragment containing the $n u c A$ gene was PCR-amplified from pVE5524 using primers $a$ and $b$ (Table 2), digested with SalI-EcoRV and ligated into similarly digested pVE5524 and pVE5523, yielding pAW004 and pAW005. To facilitate detection of E. coli clones that harbor $\operatorname{cip} A$ fragments, a lacZ- $\alpha$ stuffer fragment was PCR-amplified from pUC19 using primers $c$ and $d$, digested with $A s c \mathrm{I}-N o t \mathrm{I}$, and subsequently ligated into similarly cut pAW004 and pAW005, yielding pAW004Z and pAW005Z, respectively. Since L. lactis HtrA NZ9000 is resistant to erythromycin, the ery marker of the pAW vectors was replaced with the cat gene from pSCNIII. The cat gene was PCR-amplified using primers $e$ and $f$, digested with $A f l \mathrm{II}$ and HpaI, and ligated into similarly digested pAW004Z and pAW005Z, yielding plasmids pAW004ZC and pAW005ZC, respectively. For inducible expression of the scaffolds, we replaced the P59 promoter with $P_{\text {nisA }}$ from pSIP502. The $P_{\text {nisA }}$ promoter was isolated using primers $o$ and $p$, digested with ApaI-NruI and ligated to similarly digested pAW004ZC and pAW005ZC, yielding pAW104 and pAW105, respectively.

\section{Cloning of cipA fragments from $C$. thermocellum}

Five unique cipA fragments were PCR-amplified from $C$. thermocellum genomic DNA using primer pairs $g-h$, $i-j, g-k, l-m$ and $n-m$ (Table 2), ligated into pGEM-T (Promega) and sequenced to verify the integrity of the gene sequence. The resulting pGEM plasmids were digested with AscI-NotI to release the cipA gene fragments and these were ligated into pAW004ZC and pAW005ZC. The cipA fragments were chosen on the basis of containing a single cohesin (coh1 or coh9), two cohesins of identical specificity (coh1-coh2), one cohesin and a cellulose-binding module (coh3-CBM3a) and only a cellulose-binding module (CBM3a) (Fig. 1). The resulting $s p_{\mathrm{Usp} 45^{-}} n u c A-c i p A_{\mathrm{frag}}-c w a_{\mathrm{M} 6}$ cassettes were under control of the $P_{59}$ promoter and contained $r b s_{u s p 45}$. The same cipA fragments were cloned into pAW104 and pAW105 for inducible expression of the scaffold proteins.

For the inducible expression of the fusion proteins under the control of $P_{n i s A}$ with an intact ribosome-binding site from the nis $A$ gene $\left(r b s_{n i s A}\right), s p_{\mathrm{Usp} 45^{-}-n u c A}$ was PCR-amplified from pAW004ZC using primers $q$ and $r$, creating a $B s p \mathrm{HI}$ cut site at the $5^{\prime}$ end of the PCR product. The PCR product was digested with $B s p \mathrm{HI}$ and XhoI and ligated to pSIP502 digested with NcoI-XhoI, effectively replacing the gusA gene with $s p_{\mathrm{Usp} 45}-n u c A$, retaining the first lysine of the signal peptide, and 
Table 1 Strains and plasmids used in this study

\begin{tabular}{|c|c|c|}
\hline Strain & Genotype/Decription & Source \\
\hline L. lactis HtrA NZ9000 & MG1363 (nisRK genes on the chromosome) & {$[37]$} \\
\hline E. coli TG1 & supE thi-1 $\triangle($ lac-proAB) $\triangle($ mcrB-hsdSM)5 (rK- mK-) [F' traD36 proAB laclqZDM15] & ATCC \\
\hline E. coli DH5 $\alpha$ & fhuA2 $\triangle$ (argF-lacZ)U169 phoA glnV44 $\Phi 80 \Delta($ lacZ)M15 gyrA96 recA1 relA1 endA1 thi-1 hsdR17 & Invitrogen \\
\hline E. coli BL21 (DE3) & F ompT gal dcm lon hsdS ${ }_{B}\left(r_{B}^{-} m_{B}^{-}\right) \lambda(D E 3$ [lacl lacUV5-T7 gene 1 ind1 sam7 nin5]) & Novagen \\
\hline \multicolumn{3}{|l|}{ Plasmid } \\
\hline pVE5524 & 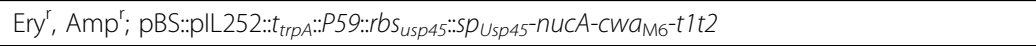 & {$[36]$} \\
\hline pVE5523 & 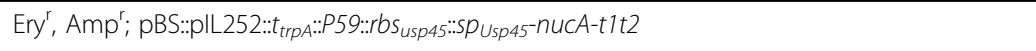 & [36] \\
\hline pSIP502 & 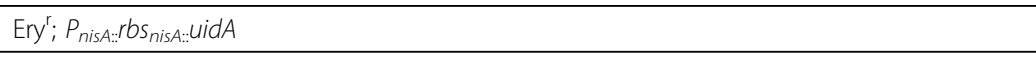 & {$[66]$} \\
\hline$\overline{\mathrm{pSCNIII}}$ & $\mathrm{Cm}^{r}$ & J. Seegers ${ }^{a}$ \\
\hline pUC19 & $A m p^{r}$ & {$[69]$} \\
\hline $\mathrm{pET} 28(\mathrm{~b})$ & $\mathrm{Km}^{\mathrm{r}}$ & Novagen \\
\hline pSIPsp-nuc & 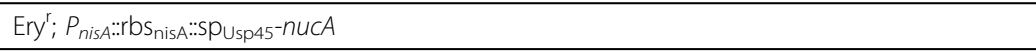 & This Work \\
\hline pUC104 & 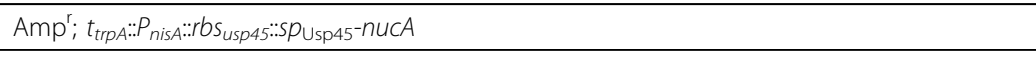 & This Work \\
\hline pUC104mod & Amp $^{r} ; t_{\operatorname{trp} A:: P 59:: r b s_{u s p 45}:: S p_{\text {Usp } 45}-n u c A}$ & This Work \\
\hline pUC304 & 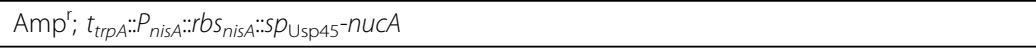 & This Work \\
\hline pUC504 & 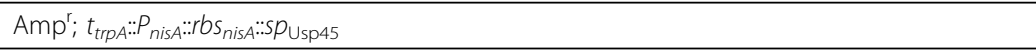 & This Work \\
\hline pAW004 & 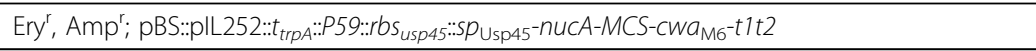 & This Work \\
\hline pAW005 & 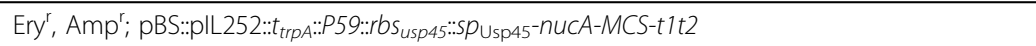 & This Work \\
\hline pAW004Z & 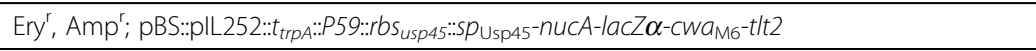 & This Work \\
\hline pAW005Z & 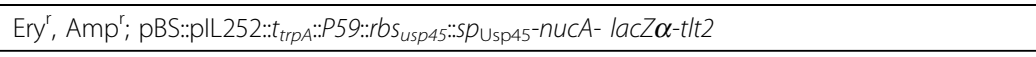 & This Work \\
\hline pAW004ZC & 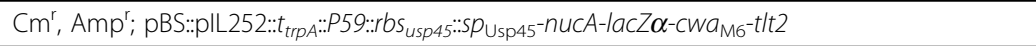 & This Work \\
\hline pAW005ZC & 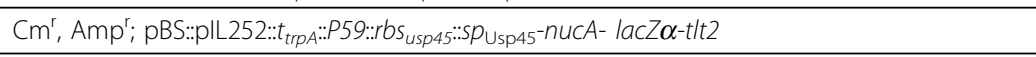 & This Work \\
\hline pGEMc9 & Ampr; pGEMT:::with cloned coh9 from cipA & This Work \\
\hline pGEMc1 & Ampr; pGEMT:::with cloned coh1 from cipA & This Work \\
\hline pGEMc1-c2 & Amp ${ }^{\text {r; }}$ pGEMT:::with cloned coh1-coh2 from cipA & This Work \\
\hline pGEMcbm-c3 & Amp ${ }^{\text {; }}$ pGEMT:: with cloned cbm3a-coh3 from cipA & This Work \\
\hline pGEMcbm & Ampr; pGEMT:::with cloned cbm3a from cipA & This Work \\
\hline pAW104 & 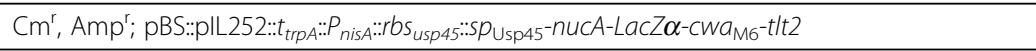 & This Work \\
\hline pAW105 & 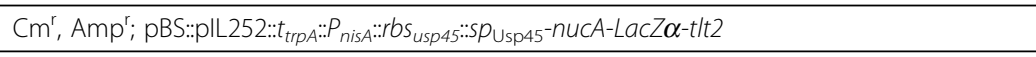 & This Work \\
\hline pAW301 & 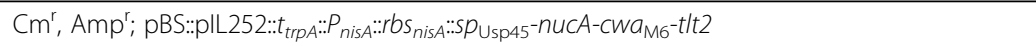 & This Work \\
\hline pAW302 & 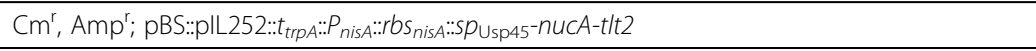 & This Work \\
\hline pAW304 & 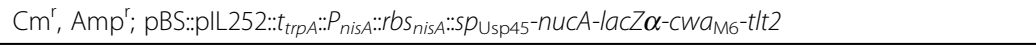 & This Work \\
\hline pAW305 & 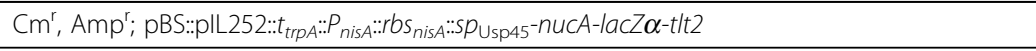 & This Work \\
\hline pAW307 & 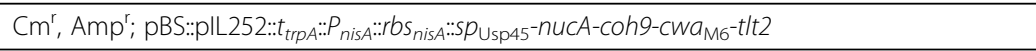 & This Work \\
\hline pAW308 & 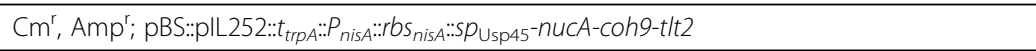 & This Work \\
\hline pAW310 & 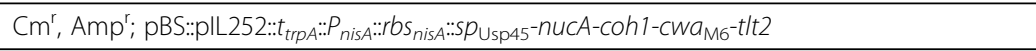 & This Work \\
\hline pAW311 & 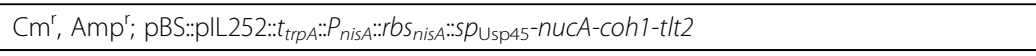 & This Work \\
\hline pAW334 & 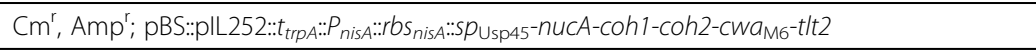 & This Work \\
\hline pAW335 & 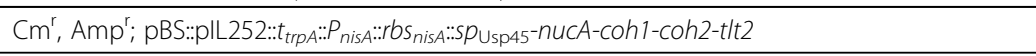 & This Work \\
\hline pAW328 & 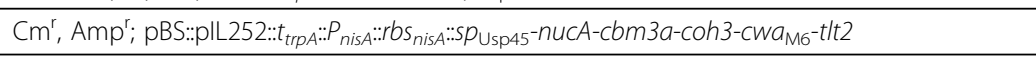 & This Work \\
\hline pAW329 & 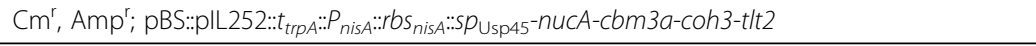 & This Work \\
\hline pAW331 & 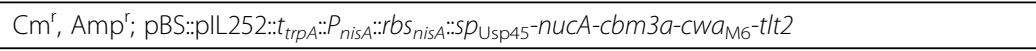 & This Work \\
\hline pAW332 & 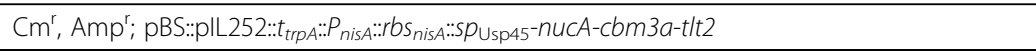 & This Work \\
\hline pAW504 & 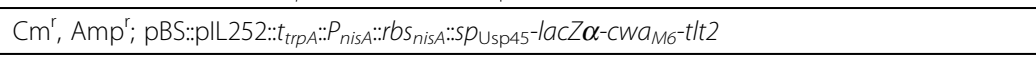 & This Work \\
\hline pAW505 & 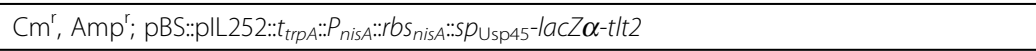 & This Work \\
\hline pAW507 & 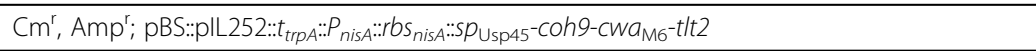 & This Work \\
\hline
\end{tabular}


Table 1 Strains and plasmids used in this study (Continued)

\begin{tabular}{|c|c|c|}
\hline pAW508 & 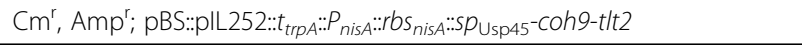 & This Work \\
\hline pAW510 & 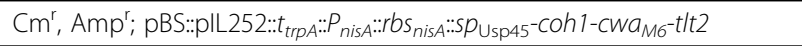 & This Work \\
\hline pAW511 & 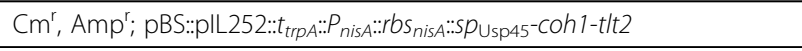 & This Work \\
\hline pAW534 & 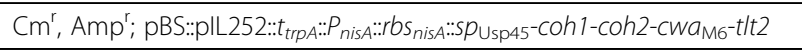 & This Work \\
\hline pAW535 & 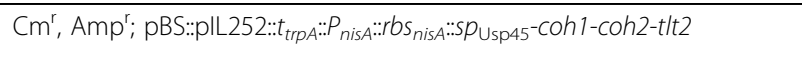 & This Work \\
\hline pAW528 & 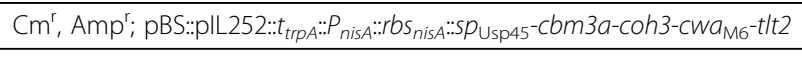 & This Work \\
\hline pAW529 & 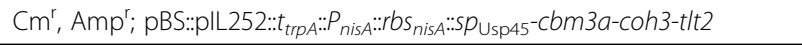 & This Work \\
\hline pAW531 & 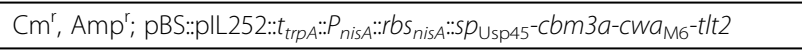 & This Work \\
\hline pAW532 & 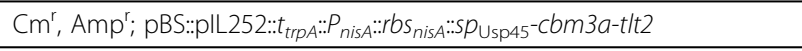 & This Work \\
\hline pETdock1 & $\mathrm{Kn}^{\mathrm{r}}$; pET28(b)::"with cloned dock1 from cels & This Work \\
\hline pETUdock1 & $\mathrm{Kn}^{\mathrm{r}} ; \mathrm{pET} 28(\mathrm{~b})::$ PT7::6xHis-uidA-dock1 & This Work \\
\hline$\overline{\mathrm{pETU}}$ & $\mathrm{Kn}^{\mathrm{r}} ; \mathrm{pET} 28(\mathrm{~b})::$ PT7::6xHis-uidA & This Work \\
\hline
\end{tabular}

${ }^{a}$ Vector pSCNIII was a gift provided by Jos Seegers (unpublished data).

pAW100 series of vectors are nisin-inducible and contain an intact $r b s_{u s p 45}$. pAW300 series vectors are nisin-inducible and contain an intact $r b s_{\text {nisa }}$. pAW500 series vectors are pAW300 variants lacking an N-terminal NucA fusion. P59, constitutive lactococcal promoter; $P T 7$, inducible T7 promoter; $P_{\text {nisA, }}$ inducible nis $A$ promoter; $r b s_{u s p 45}$, Usp45 ribosome-binding site; $r b s_{\text {nisA }}, n i s A$ ribosome-binding site; $s p_{\text {Usp45, }}$ signal sequence of Usp45; nucA, staphylococcal nuclease; $c w a_{\mathrm{M} 6}$, anchor motif of M6 protein; Ilt2, transcriptional terminator of $r r n B$ operon; $t_{t r p A}$, transcriptional terminator of $\operatorname{trpA}$.

yielding pSIPSPNUC. For the insertion of an upstream transcriptional terminator and removal of $n u c A$, a 1500 bp SapI-XbaI fragment was temporarily removed from pAW104, and was ligated to similarly cut pUC19, yielding vector pUC104. To introduce the E. coli transcriptional terminator from the tryptophan synthase operon $\left(t_{\text {trpA }}\right)$ upstream of $P_{n i s A}$ and to introduce a $B g l \mathrm{II}$ cut site, a 200-bp fragment containing $t_{t r p A}$ was PCR-amplified from pVE5524 using primers $s$ and $t$, digested with AflIII-NruI and ligated to similarly-cut pUC104, yielding pUC104mod. Plasmid pSIPSPNUC was digested with $B g l \mathrm{II}-\mathrm{XhoI}$ and ligated to similarly-digested pUC104mod, yielding vector pUC304. This was the base vector harboring the $t_{t r p A}-P_{n i s A}-r b s_{n i s A}-s p_{\mathrm{Usp} 45}-n u c A$ cassette, which was digested with $A p a \mathrm{I}-A s c \mathrm{I}$ and ligated into the pAW100 series of vectors. Inserting this cassette into ApaI-EcoRV digested pAW110 and pAW111, yielding pAW301 and pAW302, respectively, created controls lacking $\operatorname{cip} A$ fragments for expression of $n u c A$ alone. For deletion of the $n u c A$ reporter and construction of the pAW500 series, pUC304 was digested with SalI$X h o I$ and self-ligated, yielding vector pUC504. The $t_{t r p A^{-}}$ $P_{n i s A^{-}}-r b s_{\text {nis }}-s p_{\text {Usp } 45}$ cassette was released via digestion with $A p a \mathrm{I}-A s c \mathrm{I}$, gel-purified, and ligated to similarly-cut pAW100 series vectors, yielding the pAW500 series of vectors. This cassette was also ligated into similarly cut pAW104 and pAW105 yielding base vectors containing the lacZ- $\alpha$ stuffer fragment. The final expression vectors for this study included the pAW300 series of vectors for inducible expression and targeting of NucA-fused scaffolds, and the pAW500 series of vectors for inducible expression and targeting of scaffolds lacking the $\mathrm{N}$-terminal NucA reporter (Fig. 1).

\section{Expression and localization of CipA $\mathrm{A}_{\text {frags }}$ in L. lactis}

L. lactis HtrANZ9000 was transformed with the pAW300 and pAW500 series of vectors for the controlled expression of scaffolds. It contains chromosomal copies of the nisR and nisK genes necessary for nisininducible expression of cassettes under control of the nisA promoter, and is deficient in a major extracellular housekeeping protease, which has been shown previously to be responsible for the proteolysis of exported recombinant proteins [37]. Growth curves were used to evaluate the potential of growth inhibition caused by the over-expressed Cip $A_{\text {frag }}$ proteins. Growth curves were performed in 96 well plates and cells were induced with $10 \mathrm{ng}$ nisin $/ \mathrm{mL}$ at inoculation ( $\mathrm{t}=0 \mathrm{hrs}), 4 \mathrm{hrs}$ postinoculation $(t=4 \mathrm{hrs})$ or were not induced. For the expression of $\mathrm{CipA}_{\text {frag }}$ proteins in L. lactis $\mathrm{HtrA}$ NZ9000, overnight cultures were diluted 1/50 into fresh GM17 medium and were induced with $10 \mathrm{ng}$ nisin $/ \mathrm{mL}$ when an $\mathrm{OD}_{600} \approx 0.3$ was reached ( $4 \mathrm{hrs}$ ). After $20 \mathrm{hrs}$ growth, successful Cip $\mathrm{A}_{\text {frag }}$ secretion was evaluated using a nuclease assay consisting of spotting cells on TBD-agar and observing pink color formation [36]. For analysis of NucA-CipA $A_{\text {frag }}$ proteins in various cellular locations, cell fractionation was performed as described previously [58], with the addition of lysostaphin (0.6 $\mathrm{mg} / \mathrm{mL}$ ) [67]. Aliquots of proteins were blotted on TBD-agar plates and formation of a pink color was analyzed after a $1-\mathrm{hr}$ incubation at $37^{\circ} \mathrm{C}$.

\section{Expression and purification of $\mathrm{CipA}_{\text {frag }}$-binding $\beta$-glucuronidase}

The E. coli $\beta$-glucuronidase (UidA) was engineered to have a $\mathrm{C}$-terminal dock 1 module for binding onto 
$\mathrm{CipA}_{\text {frag }}$ scaffolds, as well as an N-terminal $6 \times$ His-tag for protein purification. The dock 1 module of the $C$. thermocellum celS gene was amplified from C. thermocellum genomic DNA using primers $u$ and $v$ (Table 2). PCR products were digested with EcoRI-NotI and ligated to similarly-digested pET28(b), yielding pETdock1. The uidA gene lacking a stop codon was amplified using primers $w$ and $x$ and pSIP502 as template. The PCR product was digested with NheI-EcoRI and ligated to similarly-cut pET28(b) and pETdock1, yielding His-tagged UidA proteins with and without a dock1 module (pETUdock1 and pETU). His-tagged proteins were expressed in E. coli BL21(DE3). Cultures were induced at an $\mathrm{OD}_{600}$ of 0.5 with $1 \mathrm{mM}$ IPTG and incubated for an additional $5 \mathrm{hrs}$ at $37^{\circ} \mathrm{C}$. Cells were harvested $\left(1000 \times \mathrm{g}, 10 \mathrm{~min}, 4^{\circ} \mathrm{C}\right)$ and cell pellets were kept overnight at $-80^{\circ} \mathrm{C}$. Thawed cell pellets were suspended in $50 \mathrm{mM}$ phosphate buffer, $\mathrm{pH} 7.5$, containing $300 \mathrm{mM}$ $\mathrm{NaCl}$. Samples were subjected to sonication (15 sec pulse, $5 \mathrm{sec}$ between pulses, 2 min total process time) and lysates were loaded on approximately $10 \mathrm{~mL}$ of $\mathrm{Ni}$ NTA sepharose resin. The resin was washed with phosphate buffer (50 mM, pH 6.0) containing $300 \mathrm{mM} \mathrm{NaCl}$ and $20 \mathrm{mM}$ imidazole and eluted using the same buffer containing $250 \mathrm{mM}$ imidazole. Fifty $\mu \mathrm{L}$ of each elution fraction were added to $450 \mu \mathrm{L}$ GUS buffer containing

Table 2 Primers used in this study

\begin{tabular}{|c|c|}
\hline Primer & Sequence $\left(5^{\prime}-3^{\prime}\right)$ \\
\hline $\bar{a}$ & TATAGATCTTCGATAGCCCGCCTAATGAGC \\
\hline$b$ & ATGATATCGCGGCCGCGGCGCGCCTCGAGATCGATTTG \\
\hline c & TAGATATCGGCGCGCCATTAGCTATGCGGCATCAGAGC \\
\hline$d$ & TAGCTAGCGCGGCCGCGCCCAATACGCAAACCGCCTC \\
\hline e & GATCTAGCCTTAAGTTCAACAAACTCTAGCGCC \\
\hline$f$ & CGTAGATCGTTAACCCTTCTTCAACTAACGGGG \\
\hline$g$ & TCGAGGCGCGCCCGGCCACAATGACAGTCGAGA \\
\hline$h$ & TCGAGCGGCCGCCGGTACGGAACTACCAAGAT \\
\hline i & TAGGCGCGCCATAAGTTGACACTTAAGATAGGCAG \\
\hline j & TAGCGGCCGCAGTTACAAGTACTCCACCATTG \\
\hline k & TCGAGCGGCCGCCGGTGTTGCATTGCCAACGT \\
\hline 1 & TCGAGGCGCGCCCGGATGATCCGAATGCAATAAAG \\
\hline$m$ & TCGAGCGGCCGCTACTACACTGCCACCGG \\
\hline$n$ & TGAGGCGCGCCCGGCAAATACACCGGTATC \\
\hline 0 & ATGCGGGCCCGACCTAGTCTTATAACTATACTG \\
\hline$p$ & ATGTACTCGCGATTTATITTGTAGTTCCTTCGAACG \\
\hline 9 & AGAACAGTCATGAAAAAAAAGATTATCTC \\
\hline$r$ & ATATCTCGAGATCGATTTGACCTGAATCA \\
\hline s & AGTCACATGTTCTTTCCTGCGTTATCCCCTG \\
\hline$t$ & ATGCTCGCGAAGATCTGGGATCAAAAAAAAGCCCGC \\
\hline$u$ & GCTTGAATTCTCTACTAAATTATACGGCGACGTCAATG \\
\hline$v$ & GCTTGCGGCCGCTITAGTTCTTGTACGGCAATGTATC \\
\hline$w$ & ATGCGCTAGCATGTTACGTCCTGTAGAAACC \\
\hline
\end{tabular}

Restriction enzyme cut sites are in bold.
$50 \mathrm{mM}$ sodium phosphate buffer ( $\mathrm{pH} 7), 10 \mathrm{mM} \beta$-mercaptoethanol, $1 \mathrm{mM}$ ethylenediaminetetraacetic acid and $0.1 \%(\mathrm{v} / \mathrm{v})$ Triton X-100. Samples were heated for $1 \mathrm{~min}$, after which $p$-nitrophenyl- $\beta$-D-glucuronide was added to a final concentration of $4 \mathrm{mg} / \mathrm{mL}$ [68]. The UidA-containing fractions were identified by the appearance of a yellow color. Proteins from the elution fractions showing UidA activity were visualized by SDSPAGE on a $12 \%(\mathrm{w} / \mathrm{v})$ gel to identify fractions containing the highest purity of enzyme. The specific activities of UidA-dock1 and UidA were determined by colorimetric assays in a thermostated UV-Vis spectrophotometer (Cary $50 \mathrm{WinUv}$ ) at $405 \mathrm{~nm}$, using a $1 \mathrm{~cm}$ (L) cuvette, and the known molar extinction coefficient of $p$-nitrophenol being $18000 \mathrm{M}^{-1} \mathrm{~cm}^{-1}$. Quantification of the proteins was done using a Bradford protein assay kit (Pierce) and BSA as a standard. Specific activities were used to evaluate the amount of enzyme bound to cells in the in vivo binding assay described below.

\section{Binding of $\beta$-glucuronidase to $L$. lactis}

L. lactis HtrA NZ9000 cells harboring the pAW300 or pAW500 series of vectors, as well as the plasmid-free strain were grown overnight in GM17 medium. Cultures were diluted $1 / 50$ in $5 \mathrm{~mL}$ of fresh media and grown for an additional $4 \mathrm{hrs}\left(\mathrm{OD}_{600} \approx 0.3\right)$ after which cells were induced with $10 \mathrm{ng}$ nisin/mL for scaffold expression. After 20 hrs of growth, cells from 1-mL of culture were harvested $\left(4,300 \times \mathrm{g}, 5 \mathrm{~min}, 4^{\circ} \mathrm{C}\right)$ washed once in phosphate buffer (50 mM, pH 6.0) containing $300 \mathrm{mM} \mathrm{NaCl}$ and suspended in $100 \mu \mathrm{L}$ of purified UidA-dock 1 or UidA at a concentration $100 \mu \mathrm{g} / \mathrm{mL}$. To ensure that saturation of all cohesin sites was achieved, binding assay with $200 \mu \mathrm{g}$ UidA-dock $1 / \mathrm{mL}$ was tested for L. lactis harboring pAW328. Binding was carried out at $4^{\circ} \mathrm{C}$ for $10 \mathrm{hrs}$. Cells were then washed 6 times to eliminate residual enzyme activity and suspended in $100 \mu \mathrm{L}$ of phosphate buffer (50 mM, pH 6.0) containing $300 \mathrm{mM} \mathrm{NaCl}$ for detection of $\beta$-glucuronidase activity. For quantification of bound UdiA-dock1, $50 \mu \mathrm{L}$ of washed cells were analyzed for $\beta$-glucuronidase activity. Reactions were stopped with $250 \mu \mathrm{L}$ of $1 \mathrm{M}$ sodium carbonate once a yellow color appeared, and the duration of each assay was recorded. The specific activities of the purified UidA-dock1 and UidA were used to determine the amount of enzyme bound onto the L lactis cells. Using the calculated molecular weight of UidA-dock1 and the known amount of cells present in each sample, the average number of enzyme units bound per cell was estimated. Assuming a 1:1 cohesin to dockerin ratio, the number of enzymes present per cell also is a representation of the number of cohesins present on the cell surface. The calculated molecular weight of the scaffolds was used to estimate the net amount of recombinant 
protein anchored to cells in respective cultures. Experiments were repeated twice and true biological replicates (independent colonies and cultures) were performed in triplicate for all samples.

\section{Acknowledgements}

We are grateful to Dr. Alexandra Gruss and Dr. Isabelle Poquet for providing base expression vectors for $L A B$ as well as strains of $L$. lactis. The authors would like to acknowledge Dr. Andy Ekins for his help in reviewing the manuscript. This work was supported by research grants from the Natural Sciences and Engineering Research Council of Canada (NSERC) (grant numbers 312357-06 and 330781-06) the Canada Foundation for Innovation (grant number 202359) and a Canada Research Chair to V.J.J.M. A.S.W. is the recipient of graduate scholarships from NSERC and the Fonds Québécois de la Recherche sur la Nature et les Technologies.

\section{Authors' contributions}

VM defined the strategy described and supervised the project. AW designed and carried out all experiments. AW drafted the initial manuscript, VM helped draft the manuscript, and both AW and VM edited the manuscript. VM supervised the entire PhD project of AW. All authors read and approved the final manuscript

\section{Competing interests}

The authors declare that they have no competing interests.

Received: 1 June 2010 Accepted: 14 September 2010

Published: 14 September 2010

\section{References}

1. Lowell GH, Ballou WR, Smith LF, Wirtz RA, Zollinger WD, Hockmeyer WT: Proteosome-lipopeptide vaccines: enhancement of immunogenicity for malaria CS peptides. Science 1988, 240:800-802.

2. Lowell GH, Smith LF, Seid RC, Zollinger WD: Peptides bound to proteosomes via hydrophobic feet become highly immunogenic without adjuvants. J Exp Med 1988, 167:658-663.

3. Bayer EA, Belaich JP, Shoham Y, Lamed R: The cellulosomes: multienzyme machines for degradation of plant cell wall polysaccharides. Annu Rev Microbiol 2004, 58:521-554.

4. Conrado RJ, Varner JD, DeLisa MP: Engineering the spatial organization of metabolic enzymes: mimicking nature's synergy. Curr Opin Biotechnol 2008, 19:492-499.

5. Dueber JE, Wu GC, Malmirchegini GR, Moon TS, Petzold CJ, Ullal AV Prather KL, Keasling JD: Synthetic protein scaffolds provide modular control over metabolic flux. Nat Biotechnol 2009, 27:753-759.

6. Lynd LR, Weimer PJ, van ZyI WH, Pretorius IS: Microbial cellulose utilization: fundamentals and biotechnology. Microbiol Mol Biol Rev 2002 66:506-577, table of contents.

7. Schwarz WH: The cellulosome and cellulose degradation by anaerobic bacteria. Appl Microbiol Biotechnol 2001, 56:634-649.

8. Kruus K, Lua AC, Demain AL, Wu JH: The anchorage function of CipA (CelL), a scaffolding protein of the Clostridium thermocellum cellulosome. Proc Natl Acad Sci USA 1995, 92:9254-9258.

9. Leibovitz E, Beguin P: A new type of cohesin domain that specifically binds the dockerin domain of the Clostridium thermocellum cellulosomeintegrating protein CipA. J Bacteriol 1996, 178:3077-3084.

10. Lemaire M, Ohayon H, Gounon P, Fujino T, Beguin P: OlpB, a new outer layer protein of Clostridium thermocellum, and binding of its S-layer-like domains to components of the cell envelope. J Bacteriol 1995, 177:2451-2459.

11. Kosugi A, Amano Y, Murashima K, Doi RH: Hydrophilic domains of scaffolding protein CbpA promote glycosyl hydrolase activity and localization of cellulosomes to the cell surface of Clostridium cellulovorans. J Bacteriol 2004, 186:6351-6359.

12. Garcia-Campayo V, Beguin P: Synergism between the cellulosomeintegrating protein CipA and endoglucanase CelD of Clostridium thermocellum. J Biotechnol 1997, 57:39-47.

13. Zverlov W, Klupp M, Krauss J, Schwarz WH: Mutations in the scaffoldin gene, cipA, of Clostridium thermocellum with impaired cellulosome formation and cellulose hydrolysis: insertions of a new transposable element, IS1447, and implications for cellulase synergism on crystalline cellulose. J Bacteriol 2008, 190:4321-4327.

14. Lynd LR, van Zyl WH, McBride JE, Laser M: Consolidated bioprocessing of cellulosic biomass: an update. Curr Opin Biotechnol 2005, 16:577-583.

15. Lu Y, Zhang YH, Lynd LR: Enzyme-microbe synergy during cellulose hydrolysis by Clostridium thermocellum. Proc Natl Acad Sci USA 2006, 103:16165-16169.

16. Miron J, Ben-Ghedalia D, Morrison M: Invited review: adhesion mechanisms of rumen cellulolytic bacteria. J Dairy Sci 2001, 84:1294-1309.

17. Bayer EA, Kenig R, Lamed R: Adherence of Clostridium thermocellum to cellulose. J Bacteriol 1983, 156:818-827.

18. Ng TK, Weimer TK, Zeikus JG: Cellulolytic and physiological properties of Clostridium thermocellum. Arch Microbiol 1977, 114:1-7.

19. Fierobe HP, Bayer EA, Tardif C, Czjzek M, Mechaly A, Belaich A, Lamed R, Shoham Y, Belaich JP: Degradation of cellulose substrates by cellulosome chimeras. Substrate targeting versus proximity of enzyme components. $J$ Biol Chem 2002, 277:49621-49630.

20. Fierobe HP, Mechaly A, Tardif C, Belaich A, Lamed R, Shoham Y, Belaich JP, Bayer EA: Design and production of active cellulosome chimeras. Selective incorporation of dockerin-containing enzymes into defined functional complexes. J Biol Chem 2001, 276:21257-21261.

21. Fierobe HP, Mingardon F, Mechaly A, Belaich A, Rincon MT, Pages S, Lamed R, Tardif C, Belaich JP, Bayer EA: Action of designer cellulosomes on homogeneous versus complex substrates: controlled incorporation of three distinct enzymes into a defined trifunctional scaffoldin. $J$ Biol Chem 2005, 280:16325-16334

22. Mingardon F, Chanal A, Tardif C, Bayer EA, Fierobe HP: Exploration of new geometries in cellulosome-like chimeras. Appl Environ Microbiol 2007, 73:7138-7149.

23. Murashima K, Kosugi A, Doi RH: Synergistic effects on crystalline cellulose degradation between cellulosomal cellulases from Clostridium cellulovorans. J Bacteriol 2002, 184:5088-5095.

24. Perret S, Casalot L, Fierobe HP, Tardif C, Sabathe F, Belaich JP, Belaich A: Production of heterologous and chimeric scaffoldins by Clostridium acetobutylicum ATCC 824. J Bacteriol 2004, 186:253-257.

25. Sabathe F, Soucaille P: Characterization of the CipA scaffolding protein and in vivo production of a minicellulosome in Clostridium acetobutylicum. J Bacteriol 2003, 185:1092-1096.

26. Ito J, Kosugi A, Tanaka T, Kuroda K, Shibasaki S, Ogino C, Ueda M, Fukuda H, Doi RH, Kondo A: Regulation of the display ratio of enzymes on the Saccharomyces cerevisiae cell surface by the immunoglobulin $\mathrm{G}$ and cellulosomal enzyme binding domains. Appl Environ Microbiol 2009, 75:4149-4154.

27. Tsai SL, Oh J, Singh S, Chen R, Chen W: Functional assembly of minicellulosomes on the Saccharomyces cerevisiae cell surface for cellulose hydrolysis and ethanol production. Appl Environ Microbiol 2009, 75:6087-6093.

28. Lilly M, Fierobe HP, van Zyl WH, Volschenk H: Heterologous expression of a Clostridium minicellulosome in Saccharomyces cerevisiae. FEMS Yeast Res 2009, 9:1236-1249.

29. Wen F, Sun J, Zhao H: Yeast surface display of trifunctional minicellulosomes for simultaneous saccharification and fermentation of cellulose to ethanol. Appl Environ Microbiol 76:1251-1260.

30. Petrov K, Urshev Z, Petrova P: L+-lactic acid production from starch by a novel amylolytic Lactococcus lactis subsp. lactis B84. Food Microbiol 2008, 25:550-557.

31. Hernandez I, Molenaar D, Beekwilder J, Bouwmeester $\mathrm{H}$, van Hylckama Vlieg JE: Expression of plant flavor genes in Lactococcus lactis. Appl Environ Microbiol 2007, 73:1544-1552.

32. Le Loir Y, Azevedo V, Oliveira SC, Freitas DA, Miyoshi A, BermudezHumaran LG, Nouaille S, Ribeiro LA, Leclercq S, Gabriel JE, et al: Protein secretion in Lactococcus lactis : an efficient way to increase the overall heterologous protein production. Microb Cell Fact 2005, 4:2.

33. Narita J, Okano K, Kitao T, Ishida S, Sewaki T, Sung MH, Fukuda H, Kondo A: Display of alpha-amylase on the surface of Lactobacillus casei cells by use of the PgsA anchor protein, and production of lactic acid from starch. Appl Environ Microbiol 2006, 72:269-275.

34. Zhang YH, Lynd LR: Regulation of cellulase synthesis in batch and continuous cultures of Clostridium thermocellum. J Bacteriol 2005, 187:99-106. 
35. Dieye Y, Hoekman AJ, Clier F, Juillard V, Boot HJ, Piard JC: Ability of Lactococcus lactis to export viral capsid antigens: a crucial step for development of live vaccines. Appl Environ Microbiol 2003, 69:7281-7288.

36. Dieye Y, Usai S, Clier F, Gruss A, Piard JC: Design of a protein-targeting system for lactic acid bacteria. J Bacteriol 2001, 183:4157-4166.

37. Miyoshi A, Poquet I, Azevedo V, Commissaire J, Bermudez-Humaran L, Domakova E, Le Loir Y, Oliveira SC, Gruss A, Langella P: Controlled production of stable heterologous proteins in Lactococcus lactis. Appl Environ Microbiol 2002, 68:3141-3146.

38. Ribeiro LA, Azevedo V, Le Loir Y, Oliveira SC, Dieye Y, Piard JC, Gruss A, Langella P: Production and targeting of the Brucella abortus antigen L7/L12 in Lactococcus lactis: a first step towards food-grade live vaccines against brucellosis. Appl Environ Microbiol 2002, 68:910-916.

39. Langella P, Le Loir Y: Heterologous protein secretion in Lactococcus lactis: a novel antigen delivery system. Braz J Med Biol Res 1999, 32:191-198.

40. Atsumi S, Hanai T, Liao JC: Non-fermentative pathways for synthesis of branched-chain higher alcohols as biofuels. Nature 2008, 451:86-89.

41. Zhang M, Eddy C, Deanda K, Finkelstein M, Picataggio S: Metabolic engineering of a pentose MImetabolism pathway in ethanologenic Zymomonas mobilis. Science 1995, 267:240-243.

42. Wu CH, Mulchandani A, Chen W: Versatile microbial surface-display for environmental remediation and biofuels production. Trends Microbiol 2008, 16:181-188.

43. Rittmann D, Lindner SN, Wendisch VF: Engineering of a glycerol utilization pathway for amino acid production by Corynebacterium glutamicum. Appl Environ Microbiol 2008, 74:6216-6222.

44. Lee SK, Chou H, Ham TS, Lee TS, Keasling JD: Metabolic engineering of microorganisms for biofuels production: from bugs to synthetic biology to fuels. Curr Opin Biotechnol 2008, 19:556-563.

45. Rogers PL, Jeon YJ, Lee KJ, Lawford HG: Zymomonas mobilis for fuel ethanol and higher value products. Adv Biochem Eng Biotechnol 2007, 108:263-288

46. Steen EJ, Kang Y, Bokinsky G, Hu Z, Schirmer A, McClure A, Del Cardayre SB, Keasling JD: Microbial production of fatty-acid-derived fuels and chemicals from plant biomass. Nature 463:559-562.

47. Shaw AJ, Podkaminer KK, Desai SG, Bardsley JS, Rogers SR, Thorne PG, Hogsett DA, Lynd LR: Metabolic engineering of a thermophilic bacterium to produce ethanol at high yield. Proc Natl Acad Sci USA 2008, 105:13769-13774.

48. de Vos WM: Gene expression systems for lactic acid bacteria. Curr Opin Microbiol 1999, 2:289-295.

49. Bermudez-Humaran LG, Cortes-Perez NG, Le Loir Y, Alcocer-Gonzalez JM, Tamez-Guerra RS, de Oca-Luna RM, Langella P: An inducible surface presentation system improves cellular immunity against human papillomavirus type 16 E7 antigen in mice after nasal administration with recombinant lactococci. J Med Microbiol 2004, 53:427-433.

50. Leenhouts K, Buist G, Kok J: Anchoring of proteins to lactic acid bacteria. Antonie Van Leeuwenhoek 1999, 76:367-376.

51. Gerngross UT, Romaniec MP, Kobayashi T, Huskisson NS, Demain AL: Sequencing of a Clostridium thermocellum gene ( $\operatorname{cipA}$ ) encoding the cellulosomal SL-protein reveals an unusual degree of internal homology. Mol Microbiol 1993, 8:325-334.

52. Lytle B, Myers $\mathrm{C}$, Kruus $\mathrm{K}, \mathrm{Wu} \mathrm{JH}$ : Interactions of the CelS binding ligand with various receptor domains of the Clostridium thermocellum cellulosomal scaffolding protein, CipA. J Bacterio/ 1996, 178:1200-1203.

53. Murashima K, Kosugi A, Doi RH: Solubilization of cellulosomal cellulases by fusion with cellulose-binding domain of noncellulosomal cellulase engd from Clostridium cellulovorans. Proteins 2003, 50:620-628.

54. Bermudez-Humaran LG, Langella P, Miyoshi A, Gruss A, Guerra RT, Montes de Oca-Luna R, Le Loir Y: Production of human papillomavirus type 16 E7 protein in Lactococcus lactis. Appl Environ Microbiol 2002, 68:917-922.

55. Avall-Jaaskelainen S, Lindholm A, Palva A: Surface display of the receptorbinding region of the Lactobacillus brevis S-layer protein in Lactococcus lactis provides nonadhesive lactococci with the ability to adhere to intestinal epithelial cells. Appl Environ Microbiol 2003, 69:2230-2236.

56. Cortes-Perez NG, Azevedo V, Alcocer-Gonzalez JM, Rodriguez-Padilla C, Tamez-Guerra RS, Corthier G, Gruss A, Langella P, Bermudez-Humaran LG: Cell-surface display of E7 antigen from human papillomavirus type-16 in Lactococcus lactis and in Lactobacillus plantarum using a new cell-wall anchor from lactobacilli. J Drug Target 2005, 13:89-98.
57. Lindholm A, Smeds A, Palva A: Receptor binding domain of Escherichia coli F18 fimbrial adhesin FedF can be both efficiently secreted and surface displayed in a functional form in Lactococcus lactis. Appl Environ Microbiol 2004, 70:2061-2071.

58. Piard JC, Hautefort I, Fischetti VA, Ehrlich SD, Fons M, Gruss A: Cell wall anchoring of the Streptococcus pyogenes M6 protein in various lactic acid bacteria. J Bacteriol 1997, 179:3068-3072.

59. Raha AR, Varma NR, Yusoff K, Ross E, Foo HL: Cell surface display system for Lactococcus lactis: a novel development for oral vaccine. Appl Microbiol Biotechnol 2005, 68:75-81.

60. Ramasamy R, Yasawardena S, Zomer A, Venema G, Kok J, Leenhouts K: Immunogenicity of a malaria parasite antigen displayed by Lactococcus lactis in oral immunisations. Vaccine 2006, 24:3900-3908.

61. Yang Z, Liu Q, Wang Q, Zhang Y: Novel bacterial surface display systems based on outer membrane anchoring elements from the marine bacterium Vibrio anguillarum. Appl Environ Microbiol 2008, 74:4359-4365.

62. Terzaghi BE, Sandine WE: Improved medium for lactic streptococci and their bacteriophages. Appl Microbiol 1975, 29:807-813.

63. Sambrook J, Russell DW: Molecular cloning: a laboratory manual. Cold Spring Harbor, N.Y.: Cold Spring Harbor Laboratory Press, 32001.

64. Wang WK, Wu JH: Structural features of the Clostridium thermocellum cellulase SS gene. Appl Biochem Biotechnol 1993, 39-40:149-158.

65. Holo H, Nes IF: High-frequency transformation, by electroporation, of Lactococcus lactis subsp. cremoris grown with glycine in osmotically stabilized media. Appl Environ Microbiol 1989, 55:3119-3123.

66. Sorvig E, Gronqvist S, Naterstad K, Mathiesen G, Eijsink VG, Axelsson L: Construction of vectors for inducible gene expression in Lactobacillus sakei and L plantarum. FEMS Microbiol Lett 2003, 229:119-126.

67. Steidler L, Viaene J, Fiers W, Remaut E: Functional display of a heterologous protein on the surface of Lactococcus lactis by means of the cell wall anchor of Staphylococcus aureus protein A. Appl Environ Microbiol 1998, 64:342-345.

68. Axelsson L, Lindstad G, Naterstad K: Development of an inducible gene expression system for Lactobacillus sakei. Lett Appl Microbiol 2003, 37:115-120.

69. Yanisch-Perron C, Vieira J, Messing J: Improved M13 phage cloning vectors and host strains: nucleotide sequences of the M13mp18 and pUC19 vectors. Gene 1985, 33:103-119.

doi:10.1186/1475-2859-9-69

Cite this article as: Wieczorek and Martin: Engineering the cell surface display of cohesins for assembly of cellulosome-inspired enzyme complexes on Lactococcus lactis. Microbial Cell Factories 2010 9:69.

\section{Submit your next manuscript to BioMed Central and take full advantage of:}

- Convenient online submission

- Thorough peer review

- No space constraints or color figure charges

- Immediate publication on acceptance

- Inclusion in PubMed, CAS, Scopus and Google Scholar

- Research which is freely available for redistribution

Submit your manuscript at www.biomedcentral.com/submit
C Biomed Central 